\title{
GROWTH RESPONSE OF CLOWN LOACH (Chromobotia macracanthus Bleeker 1852) JUVENILES IMMERSED IN WATER CONTAINING RECOMBINANT GROWTH HORMONE
}

\author{
Asep Permana"), Alimuddin"), Wartono Hadie" ${ }^{n+4}$, and Agus Priyadi") \\ ") Research and Development Institute for Ornamental Fish Culture \\ ") Department of Aquaculture, Faculty of Fisheries and Marine Sciences, Bogor Agricultural University (IPB) \\ $\Rightarrow$ Research and Development Center for Aquaculture
}

(Received 7 July 2015; Final revised 7 November 2015; Accepted 10 November 2015)

\begin{abstract}
The main problem in the culture of clown loach (Chromobotia macracanthus) is the slow growth rate, which takes about six months to reach its market size (two inches total body length). Slow growth eventually cause a long production time and increase the production costs. An alternative solution can be proposed in order to enhance the growth is by using recombinant growth hormone. The aim of this study was to determine the immersion dose of recombinant Epinephelus lanceolatus growth hormone (rElGH) which can generate the highest growth in clown loach. Larvae at seven day after hatching were hyperosmotic treated with $\mathrm{NaCl} 2.0 \%$ for one minute, then immersed for one hour in water containing $0.3 \% \mathrm{NaCl}, 0.01 \%$ bovine serum albumin (BSA), and different doses of rElGH, namely: 0.12 (treatment A), 1.2 (B), 12 (C), and $120 \mathrm{mg} /$ $\mathrm{L}$ (D). As control, fish were immersed in water without $\mathrm{rElGH}$ and $\mathrm{NaCl}$ (control-1), water containing $0.3 \%$ $\mathrm{NaCl}$ and $0.01 \% \mathrm{BSA}$ (control-2), and $0.3 \% \mathrm{NaCl}$ water (control-3). Each treatment was replicated three times. The results showed that clown loach juveniles in treatment $\mathrm{B}, \mathrm{C}$, and $\mathrm{D}$ had longer total body length $(\mathrm{P}<0.05)$ than control-1, while fish treatment A was the same as controls. Survival and body weight were similar in all treatments and controls $(P>0.05)$. In addition, the percentage of large size juveniles increased approximately $5 \%$ in treatment $\mathrm{B}$, almost the same as in the medium size, while the small size were decrease compared to the control- 1 . Thus, the best immersion dose of rElGH was $1.2 \mathrm{mg} / \mathrm{L}$ water.
\end{abstract}

KEYWORDS: growth hormone, larvae, clown loach, immersion

\section{INTRODUCTION}

Administration of recombinant growth hormone ( $\mathrm{rGH})$ has been reported as an effective way to increase fish growth, and mainly applied to fish for food. In ornamental fish, effectiveness of rGH treatment has been reported in goldfish (Promdonkoy et al., 2004; Acosta et al., 2009) and angelfish (Pterophyllum scalare) (Acosta et al., 2009). Several recombinant growth hormone $(\mathrm{rGH})$ of fish had recently been produced, such as giant catfish rGH (Promdonkoy et al., 2004), salmon rGH (Moriyama \& Kawauchi, 1990), tilapia rGH (Acosta et al., 2007), giant gourami and giant grouper rGH (Alimuddin et al., 2010). Among three $\mathrm{rGH}$ fish species produced in Indonesia, recombinant Epinephelus lanceolatus growth hormone $(\mathrm{rElGH})$ is widely used because its production level on $E$. coli is

\# Correspondence: Research and Development Centre for Ornamental Fish Culture. Jl. Perikanan No. 13, Pancoran Mas, Depok 16436, Indonesia. Phone: + (021) 7520482

E-mail: asep_aa37@yahoo.co.id higher compared with Cyprinus carpio ( $\mathrm{rCcGH}$ ) and Osphronemus goramy (rOgGH) (Irmawati, 2013). In addition, bioactivity of rElGH in terms of growth stimulation on tilapia is better than $\mathrm{rCcGH}$ and $\mathrm{rOgGH}$ (Alimuddin et al., 2010).

Recombinant growth hormone can be delivered by injection (Promdonkoy et al., 2004), orally via feed (Peterson et al., 2004), immersion (Acosta et al., 2007), and combination of immersion and oral methods (Handoyo, 2012). Immersion method is the most applicable to be executed on a mass scale at larval stage. Effectiveness of rGH delivery by immersion is determined by the dose and duration of treatment. Aminah (2012) reported that administration of rEIGH on eel fry by immersion for two hours at a dose of 3 $\mathrm{mg} / \mathrm{L}$, can increase biomass by $28 \%$ and survival of $15.2 \%$ higher than the control. Furthermore, immersion of eel fry in water containing rElGH for two hours at a dose $12 \mathrm{mg} / \mathrm{L}$ can increase growth by $37.4 \%$ higher than control (Handoyo, 2012). Meanwhile, immersion of white shrimp PL2 in $15 \mathrm{mg} / \mathrm{L}$ rElGH solution for 
three hours increases body weight of $109.9 \%$; body length of $26.0 \%$; and biomass of $66.0 \%$ higher compared to the control (Subaidah et al., 2012).

Clown loach aquaculture has been successfully carried out in Research and Development Institute for Ornamental Fish Culture, Depok (Satyani et al., 2006). The main problems occurred in clown loach culture is the slow growth rate, which takes about six months to reach two inches of body length (Permana et al., 2011). Therefore, efforts are needed in order to enhance the growth and shorten the rearing period of clown loach. In this study, as the first step to develop an effective rGH delivery method for clown loach, rElGH was delivered by immersion method to obtain an optimum dose that allows higher growth of clown loach juvenile.

\section{MATERIALS AND METHODS}

\section{Recombinant Growth Hormone Production}

Production of recombinant growth hormone was conducted at Laboratory of Fish Reproduction and Genetics, Department of Aquaculture, Faculty of Fisheries and Marine Sciences, IPB. Escherichia coli bacteria BL21 containing pCold-I/ElGH constructs were cultured and crude protein containing rElGH was extracted following the method of Alimuddin et al. (2010). Proteins were washed with phosphate buffer saline and kept in a deep freezer at $-80^{\circ} \mathrm{C}$ until be used.

\section{Experimental Design and Fish Rearing}

Completely randomized design was used as the experimental method on this study (Table 1). The effect of rElGH treatment was determined by analyzing the daily growth rate (DGR) and survival of clown loach immersed in rElGH solution compared with the untreated fish (control). Larvae were hyperosmotic treated in $2.0 \% \mathrm{NaCl}$ sulution for one minute, then immersed for one hour (based on preliminary research) in water containing $0.3 \% \mathrm{NaCl}, 0.01 \% \mathrm{BSA}$, and rElGH with different doses $(0.12,1.2,12$, and 120 $\mathrm{mg} / \mathrm{L}$ ), with fish density of 5 larvae/L. As control, fish were immersed in water without $\mathrm{rElGH}$ and $\mathrm{NaCl}$ (control- 1 ), water containing $0.3 \% \mathrm{NaCl}$ and $0.01 \% \mathrm{BSA}$ (control-2), and $0.3 \% \mathrm{NaCl}$ water (control-3). Three controls were used for the purpose of ensuring that the growth improvement caused only by rElGH. Each treatment was replicated three times.

Seven-day-old larvae were obtained from Institute for Research and Development for Ornamental Fish Culture, Depok, with average body length of $0.57 \mathrm{~cm}$ and body weight of $0.0019 \mathrm{~g}$. Those fish were from one broodstock. Fish were reared for 84 days in the closed recirculating system tanks $(80 \mathrm{~cm}$ x $40 \mathrm{~cm}$ x 20 $\mathrm{cm})$ and fed at satiation with Artemia nauplii for the first 30 day rearing, combination of Artemia nauplii and bloodworm for the second 15 days rearing, and bloodworm for the last 38 days rearing.

\section{Parameters and Statistical Analysis}

Parameters observed were weight daily growth rate and length daily growth rate, absolute weight and length, survival, and size variations. Fish weight and length were measured every three weeks, about 30 individuals per replication. Weight daily growth rate (LPHb) and length (LPHp) were calculated based on Effendie (1997). $\mathrm{LPHb}=\left[\left(\ln \mathrm{W}_{\mathrm{t}}-\ln \mathrm{W}_{0}\right) / \mathrm{t} \times 100\right], \mathrm{LPHp}=\left[\left(\ln \mathrm{P}_{\mathrm{t}}\right.\right.$ $\left.\left.-\ln P_{0}\right) / t \times 100\right] . W_{t}=$ average body weight at the end of the experiment $(\mathrm{g}), \mathrm{W}_{0}=$ average body weight at the initial $(\mathrm{g}), \mathrm{P}_{\mathrm{t}}=$ average total body length at the end of the experiment $(\mathrm{mm}), \mathrm{P}_{0}=$ average total body length at the initial $(\mathrm{mm}), \mathrm{t}=$ duration of study period (days). Fish survival was counted at the end of the experiment. Fish size variations were measured at the end of the study. Fish were grouped into three sizes based on total body length $(\mathrm{TL})$, small $(\mathrm{S}, \mathrm{TL}=15.5 \pm$ $4.5 \mathrm{~mm})$, medium $(\mathrm{M}, \mathrm{TL}=25.5 \pm 4.5 \mathrm{~mm})$, and large sizes $(\mathrm{L}, \mathrm{TL}=35.5 \pm 4.5 \mathrm{~mm})$.

Data of growth, survival, and variations in size were analyzed using analysis of variance (ANOVA) and Tukey's test using SPSS 17.0 software.

\section{RESULTS AND DISCUSSION}

\section{Results}

Figure 1 and Table 1 illustrated that total body length of fish treatment B $(1.2 \mathrm{mg} / \mathrm{L}), C(12 \mathrm{mg} / \mathrm{L})$, and $\mathrm{D}(120 \mathrm{mg} / \mathrm{L})$ was longer $(\mathrm{P}<0.05)$ than the control-1, whereas treatment $\mathrm{A}(0.12 \mathrm{mg} / \mathrm{L})$ was the same as all controls. Growth length of clown loach were decrease from treatment $\mathrm{B}, \mathrm{C}$, and $\mathrm{D}$ which the highest in growth obtained from treatment $B$, which is $7.3 \%$ faster than the control- 1 .

Absolute body weight and length, daily growth, and survival rates of clown loach were presented in Table 2. Table 2 showed that total body length and length daily growth rate for the treatment $\mathrm{B}, \mathrm{C}$, and $D$ were significantly higher $(P<0.05)$ than that of control-1. Total body length of fish treatment $\mathrm{D}$ was the same $(\mathrm{P}>0.05)$ with the controls. On the other hand, the administration of rElGH through immersion on clown loach larvae did not significantly affect growth rate of body weight, and survival.

Fish were immersed in water without rElGH and $\mathrm{NaCl}$ (control-1), water containing $0.3 \% \mathrm{NaCl}$ and $0.01 \%$ BSA (control-2), and $0.3 \% \mathrm{NaCl}$ water (control-3). Different superscript letters in the same row are statistically different $(\mathrm{P}<0.05)$. 


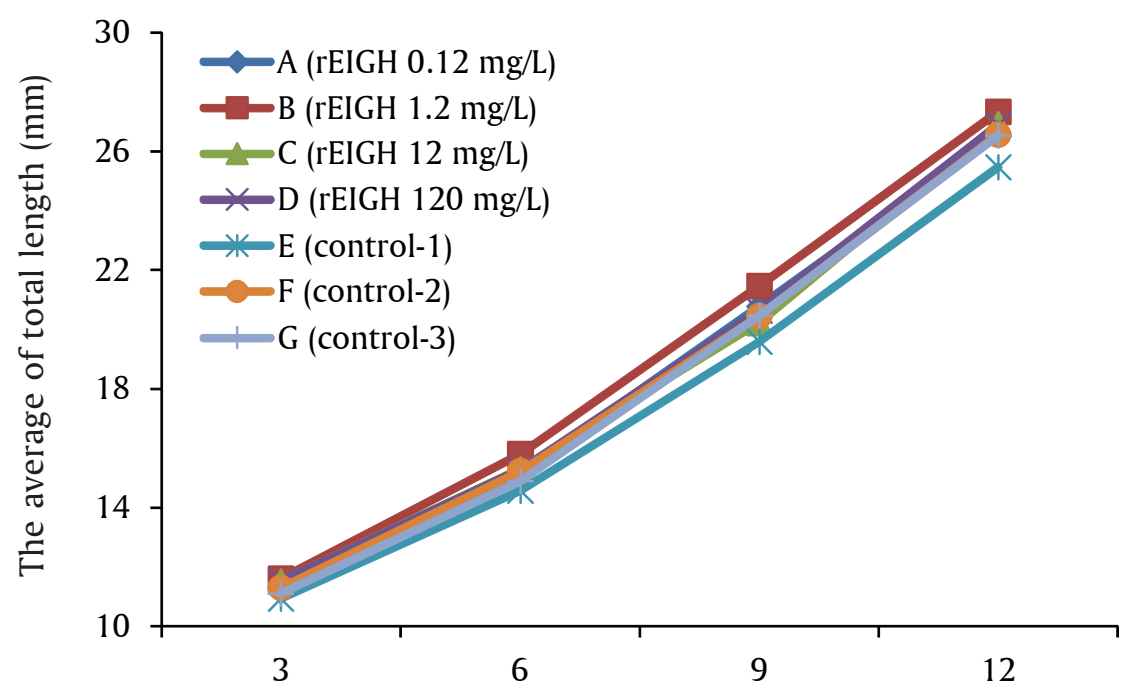

Figure 1. Growth length of clown loach (Chromobotia macracanthus) treated with different dosage of recombinan Epinephelus lanceolatus growth hormone by immersion method

Clown loach body size at the end of the study was grouped into three size, namely small $(\mathrm{S})$, medium $(\mathrm{M})$, and large (L), and the results were presented in Table 2. As shown on Table 2, the administration of rElGH through immersion on clown loach larvae did not affect $(\mathrm{P}>0.05)$ on variation of $\mathrm{S}$ and $\mathrm{M}$ size distribution, but significantly affect $(\mathrm{P}<0.05)$ on $\mathrm{L}$ size distribution at the end of the study. The size grouping was conducted based on the mean of body length and standard deviation, although this method actually has not been standardized yet, likewise on neon tetra fish, tiger barb and other ornamental fish. This size grouping was conducted only to distinguish size variations that appear after three months of fish rearing.

Recombinant growth hormone immersion was conducted once at the beginning of rearing phase with different doses. Different superscript letters in the same row are statistically different $(\mathrm{P}<0.05)$. Size $\mathrm{S}$ (small, $\mathrm{TL}=15.5 \pm 4.5 \mathrm{~mm}$ ), $\mathrm{M}$ (medium, $\mathrm{TL}=$ $25.5 \pm 4.5 \mathrm{~mm}$ ), and $\mathrm{L}$ (large, $\mathrm{TL}=35.5 \pm 4.5 \mathrm{~mm}$ ).

\section{Discussion}

Clown loach fish growth is relatively slow so the time needed to reach market sizes (two inches or 5

Table 1. Body weight and length, length daily growth rate (LDG), and weight (WGR), and survival rate of clown loach juvenile on controls and treatment of recombinant Epinephelus lanceolatus growth hormone immersion with different doses

\begin{tabular}{cccccccc}
\hline & \multicolumn{6}{c}{ rEIGH immersion doses (based on weight mass, mg/L) } \\
\cline { 2 - 7 } Parameters & $\mathrm{A} \mathrm{(0.12)}$ & $\mathrm{B}(\mathbf{1 . 2})$ & $\mathrm{C}(\mathbf{1 2})$ & $\mathrm{D}(\mathbf{1 2 0})$ & $\mathrm{E}$ (control-1) & $\mathrm{F}$ (control-2) & G (control-3) \\
\hline $\begin{array}{c}\text { Total body } \\
\text { length (mm) }\end{array}$ & $26.55 \pm 0.75^{\mathrm{ab}}$ & $27.32 \pm 0.31^{\mathrm{b}}$ & $26.92 \pm 0.61^{\mathrm{b}}$ & $26.89 \pm 0.44^{\mathrm{b}}$ & $25.46 \pm 0.17^{\mathrm{a}}$ & $26.56 \pm 0.87^{\mathrm{ab}}$ & $26.53 \pm 0.53^{\mathrm{ab}}$ \\
$\begin{array}{c}\text { Body } \\
\text { weight (g) }\end{array}$ & $2.763 \pm 0.294^{\mathrm{a}}$ & $2.907 \pm 0.156^{\mathrm{a}}$ & $2.841 \pm 0.208^{\mathrm{a}}$ & $2.898 \pm 0.088^{\mathrm{a}}$ & $2.704 \pm 0.490^{\mathrm{a}}$ & $2.824 \pm 0.199^{\mathrm{a}}$ & $2.725 \pm 0.130^{\mathrm{a}}$ \\
$\begin{array}{c}\text { Length growth } \\
\text { rate (\%) }\end{array}$ & $1.832 \pm 0.033^{\mathrm{ab}}$ & $1.866 \pm 0.015^{\mathrm{b}}$ & $1.848 \pm 0.027^{\mathrm{b}}$ & $1.847 \pm 0.019^{\mathrm{b}}$ & $1.782 \pm 0.007^{\mathrm{a}}$ & $1.832 \pm 0.039^{\mathrm{ab}}$ & $1.831 \pm 0.020^{\mathrm{ab}}$ \\
$\begin{array}{c}\text { Weight growth } \\
\text { rate (\%) }\end{array}$ & $8.669 \pm 0.125^{\mathrm{a}}$ & $8.730 \pm 0.063^{\mathrm{a}}$ & $8.702 \pm 0.087^{\mathrm{a}}$ & $8.726 \pm 0.036^{\mathrm{a}}$ & $8.643 \pm 0.202^{\mathrm{a}}$ & $8.695 \pm 0.082^{\mathrm{a}}$ & $8.653 \pm 0.057^{\mathrm{a}}$ \\
$\begin{array}{c}\text { Survival } \\
\text { rate (\%) }\end{array}$ & $82 \pm 7^{\mathrm{a}}$ & $78 \pm 6^{\mathrm{a}}$ & $90 \pm 5^{\mathrm{a}}$ & $84 \pm 2^{\mathrm{a}}$ & $76 \pm 4^{\mathrm{a}}$ & $86 \pm 5^{\mathrm{a}}$ & $82 \pm 2^{\mathrm{a}}$ \\
\hline
\end{tabular}

Note: Fish were immersed in water without rEIGH an Nacl (control-1), water containing $0.3 \%$ Nacl and $0.01 \%$ BSA (control-2), and 0.3\% $\mathrm{Nacl}$ water (control-3). Different superscript letters in the same row are statically $(\mathrm{P}<0.05)$ 
Table 2. Distribution of clown loach size variations (small/S, medium/M, and large/L) at the end of the study on control and fish treated by recombinant Epinephelus lanceolatus growth hormone with different doses

\begin{tabular}{|c|c|c|c|c|c|c|c|}
\hline \multirow{2}{*}{$\begin{array}{l}\text { Fish } \\
\text { size }\end{array}$} & \multicolumn{7}{|c|}{ rEIGH immersion dose (based on weight mass, mg/L) } \\
\hline & $\mathrm{A}(0.12)$ & B (1.2) & $\mathrm{C}(12)$ & $\mathrm{D}(\mathbf{1 2 0})$ & E (control-1) & $\mathrm{F}$ (control-2) & G (control-3) \\
\hline Size S (\%) & $30.7 \pm 2.9^{\mathrm{a}}$ & $28.1 \pm 4.8^{\mathrm{a}}$ & $27.6 \pm 3.1^{\mathrm{a}}$ & $28.4 \pm 7.0^{\mathrm{a}}$ & $34.4 \pm 10.7^{\mathrm{a}}$ & $32.2 \pm 2.0^{\mathrm{a}}$ & $29.9 \pm 2.0^{\mathrm{a}}$ \\
\hline Size M (\%) & $36.4 \pm 4.4^{\mathrm{a}}$ & $34.9 \pm 4.3^{\mathrm{a}}$ & $36.9 \pm 4.1^{\mathrm{a}}$ & $36.4 \pm 7.4^{\mathrm{a}}$ & $33.3 \pm 12.0^{\mathrm{a}}$ & $35.6 \pm 4.0^{\mathrm{a}}$ & $37.9 \pm 3.5^{\mathrm{a}}$ \\
\hline Size L $(\%)$ & $33.0 \pm 1.8^{\mathrm{abc}}$ & $37.1 \pm 0.7^{\mathrm{c}}$ & $35.6 \pm 1.1^{\mathrm{abc}}$ & $35.2 \pm 1.3^{\mathrm{abc}}$ & $32.2 \pm 1.1^{\mathrm{ab}}$ & $32.2 \pm 2.0^{\mathrm{ab}}$ & $32.2 \pm 2.0^{\mathrm{ab}}$ \\
\hline
\end{tabular}

Note: Recombinant growth hormone immersion was conducted once at the beginning of reareing phase with different doses. Different superscript letters in the sam row are statically different $(\mathrm{P}<0.05)$. Size $S$ (small, $T L=15.5 \pm 4.5 \mathrm{~mm})$, $\mathrm{M}($ medium, $\mathrm{TL}=25.5 \pm 4.5 \mathrm{~mm})$ and $\mathrm{L}$ (large, $\mathrm{TL}=35.5 \pm 4.5 \mathrm{~mm})$

$\mathrm{cm})$ is relatively long. In this sudy, treatment of clown loach by rElGH immersion at a dose of $1.2 \mathrm{mg} / \mathrm{L}$ increased length growth rate by $7.3 \%$ compared to the control-1 without rElGH immersion $(\mathrm{P}<0.05)$, while the weight and daily growth rate did not show significant difference $(\mathrm{P}>0.05)$. According to Figure 1, length growth was still possibly increased and this indicates the potential to be faster reach the size of two inches. However, compared with other studies on different commodities, these results are still lower. This is presumably due to less immersion time. Subaidah et al. (2012) obtained an increasing body weight of white shrimp about $62.21 \%$ after rElGH immersion treatment for three hours, and it is 2.3 higher than two hours of immersion treatment (26.99\%). High increase of growth rate can also be obtained by combining rGH treatment at larval stage, and oral treatment at juvenile stage (Handoyo, 2012). Thus, longer immersion time and combination of immersion and oral delivery method may allow higher growth enhancement in clown loach.

Low growth stimulation in rGH treatment can also due to low affinity of rGH on the receptor. Birzniece et al. (2009) stated that different growth effect occurs because the administered rGH was not suitable with growth hormone receptors on target fish. In our study the genetic relationship of recombinant growth hormone of giant grouper is much distant with the clown loach. However, Alimuddin et al. (2011) reported that the weight of giant gourami immersed with recombinant giant gourami growth hormone ( $\mathrm{rOgGH}$ ) showing an escalation growth by $75 \%$ higher than the control. In other study, the use of rGH tilapia on tilapia juveniles was able to increase the growth of more than $50 \%$ (Acosta et al., 2007). Those studies are using recombinant growth hormone from the same fish to the test fish. Until now, GH of clown loach has not been isolated yet, and only rElGH have been tested.

Length is a determining factor in the production of ornamental fish because ornamental fish sales are usually based on the body length. Based on these results, the growth of clown loach length can be increased through immersion treatment at a dose of $1.2 \mathrm{mg} / \mathrm{L}$. Thus the rElGH immersion treatment has a high potential to be applied by aquaculturist in order to increase production efficiency particularly rearing time efficiency. If we see it from the length daily growth rate point of view, treatment $B$ can reach market size $(5 \mathrm{~cm})$ within 117 days, it was faster one week compared with controls (123 days), by looking at the growth trends; it was still increasing until 3month-old. This also provide opportunity to reach market size $(5 \mathrm{~cm})$ more quickly if the fish were administered growth hormone again through oral on clown loach juvenile that were already immersed with growth hormone. Handoyo (2012) stated that the response of eel treated with $\mathrm{rGH}$ treatment via immersion and oral combination showing a significant improvement of LPH (41.6\%) and harvest biomass (102.9\%) compared to controls.

The enhancement of rElGH dosage from $0.12 ; 1.2$; 12 to $120 \mathrm{mg} / \mathrm{L}$ was not positively correlated with an increase on clown loach fish growth. The rElGH immersion dose at $1.2 \mathrm{mg} / \mathrm{L}$ was better than $0.12 ; 12$; and $120 \mathrm{mg} / \mathrm{L}$. This suggests that rElGH immersion with a dose of $1.2 \mathrm{mg} / \mathrm{L}$ was optimum to spur the growth of clown loach. Growth hormone administration on a low dosage would not have a positive effect on growth; conversely too high dose will have a negative effect on fish hormonal feedback (Debnanth, 2010). Negative feedback is happened hormonally, in which IGF-1 will suppress the pituitary on producing $\mathrm{GH}$, if the concentrations of $\mathrm{GH}$ in the body is excessive.

In others control treatment, showing no significant differences $(\mathrm{P}>0.05)$. This means that the administration of $0.01 \%$ BSA and salinity shock does not affect the growth of clown loach fish, as well as the rElGH treatment at a dose $0.12 \mathrm{mg} / \mathrm{L}$. The dose of $0.12 \mathrm{rElGH} \mathrm{mg} / \mathrm{L}$ allegedly too small and have not been able to influence clown loach growth. 
At the end of the study, fish size distribution was also observed and grouped into three sizes: small, medium, and large. The result showed that the growth was still relatively high at high rElGH dose, but not followed by the variation of fish size distribution. Percentage of large size fish in treatment dose of 1.2 $\mathrm{mg} / \mathrm{L}$ was higher $(\mathrm{P}<0.05)$ compared to the control (Table 3). Variation in fish size is an important factor, especially in determining the amount of fish that can be sold or not at harvesting time. More large fish than medium and small sizes, so more fish that are fit with the market size criteria. Surely it would be more profitable for the business of clown loach fish rearing.

Clown loach survival rate at the end of the study was high (76\%-90\%), and not significantly different between treatments $(\mathrm{P}>0.05)$. This high rate of survival is also due there was no infection or the presence of stress to environmental factors during the study. Several studies have shown that GH was able to increase competent cells in the immune system/ immunity directly such as lymphocytes, natural killer cells (NK cells), and macrophages (Kelley, 1989; Gala, 1991). In rainbow trout, GH was able to increase the resistance to bacterial infection of Vibrio anguillarum through the enhancement of phagocytic activity (Sakai et al., 1997). GH is also able to increase the production of superoxide anion in leukocytes and leukocyte mitogenesis (Sakai et al., 1996). While in gilthead sea bream (Sparus aurata) and seabream silver (Sparus Sarba) GH could stimulates lymphopoiesis and phagocytosis (Harris \& Bird, 2000). The presence of GH receptors was also detected on lymphocytes and monocytes of gilthead seabream (Sparus aurata) showing that $\mathrm{GH}$ is directly related to the immune system (Calduch-Giner et al., 1995).

\section{CONCLUSION}

Administration of rElGH on clown loach larvae through immersion could significantly increase growth length by $7.3 \%$ compared to the control. The best immersion dose was $1.2 \mathrm{mg} / \mathrm{L} \mathrm{rElGH}$.

\section{ACKNOWLEDGEMENT}

The authors wish to express their warmest thanks to the Research and Development Institut for Ornamental Fish Culture, Depok, Ministry of Marine Affairs and Fisheries which has giving financial support on this study implementation. We also like to thank Mr. Rendy, Hasan, Rona, Santi, and Rinal for their assistance during the research.

\section{REFERENCES}

Acosta, J.R., Morales, R., Morales, A., Alonso, M., \& Estrada, M.P. (2007). Pichia pastoris expressing recombinant tilapia growth hormone accelerates the growth of tilapia. Biotechnol. Lett., 29, 1671-1676.

Acosta, J.R., Estrada, M.P., Carpio, Y., Ruiz, O., Morales, R., Martinez, E., Valdes, J., Borroto, C., Besada, V., Sanchez, A., \& Herera, F. (2009). Tilapia somatotropin polypeptides: potent enhancers of fish growth and innate immunity. Biotechnologia Aplicada, 26, 267-272.

Alimuddin, Lesmana, I., Sudrajat, A.O., Carman, O., \& Faisal, I. (2010). Production and bioactivity potential of three recombinant growth hormones of farmed fish. Indonesian Aquaculture Journal, 5(1), 11-16.

Alimuddin, Etoh, S., Putra, H.P.G.P., \& Carman, O. (2011). Growth and survival of giant gourami juvenile immersed in different doses of recombinant growth hormone. Jurnal Akuakultur Indonesia, 10(2), 99-105.

Aminah. (2012). Aplication of giant grouper recombinant hormone on glass eel by immersed at different doses. Skripsi. Bogor Agricultural University. Bogor.

Birzniece, V., Sata, A., \& Ho, K. (2009). Growth hormone reseptor modulators. Clin. Endocrinol., (Oxf) 71(5), 715. PMID 19170715.

Calduch-Giner, J.A., Sitia-Bobadilla, A., AlvarezPellitero, P., \& Perez-Sanchez, J., (1995). Evidence for a direct action of GH on haemopoietic cells of a marine fish, the gilthead sea bream (Sparus aura). Journal Endocrinolog, 146, 459-467.

Debnanth, S. (2010). A review on the physiology of Insulin like Growth Factor-I (IGF-I) peptide in bony fishes and its phylogenetic correlation in 30 different taxa of 14 families of teleosts. Advances in Environmental Biology, 5, 31-52.

Effendie, M.I. (1997). Fisheries biology. Yayasan Pustaka Nusatama. Yogyakarta.

Gala, R.R. (1991). Prolactin and growth hormone in the regulation of the immune system. Proc. Sot. Exp. Biol. Med.,198, 513-527.

Handoyo, B. (2012). Response of eel fingerling on recombinant giant grouper growth hormone by immersion and oral administration. Thesis. Bogor Agricultural University. Bogor. Indonesia.

Harris, J., \& Bird, D.J. (2000). Modulation of the fish immune system by hormones (Mini Review). Veterinary Immunology and Immunopathology, 77, 163176. 
Irmawati, I. (2013). Physiology, biochemistry, and molecular responses of giant gourami juvenile treated by recombinant growth hormone. Dissertation. Bogor Agricultural University. Bogor. Indonesia.

Kelley, K.W. (1989). Growth hormone, lymphocytes, and macrophages. Biochemical Pharmacology, 38, 705-713.

Moriyama, S., \& Kawauchi, H. (1990). Growth stimulation of juvenile salmonids by immersion in recombinant salmon growth hormon. Nippon Suisan Gakkaishi, 56, 31-34.

Permana, A., Kusumah, V.R., \& Priyadi, A. (2011). Culture of botia fish (Chromobotia macracanthus Bleeker) as ex-situ conservation model. Prosiding Forum Nasional Pemacuan Sumber Daya Ikan III. Hasil Penelitian Perikanan dan Kelautan. Bandung.

Peterson, B.C., Small, B.C., \& Bosworth, B.G. (2004). Effect of bovine growth hormon (Posilac () ) on growth performance, body composition, and IGFBPs in two strain of channel catfish. Aquaculture, 232, 651-663.

Promdonkoy, B., Warit, S., \& Panyim, S. (2004). Production of a biologically active growth hormone from giant catfish (Pangasianodon gigas) in Escherichia coli. Biotechnol. Lett., 26, 649-653.
Sakai, M., Kobayashi, M., \& Kawauchi, H. (1996). Invitro activation of fish phagocytic cells by growth hormone. prolactin and somatolactin. Journal Endocrinology, 151, 113-118.

Sakai, M., Kajita, Y., Kobayashi, M., \& Kawauchi, H. (1997). Immunostimulating effect of growth hormone: in-vivo administration of growth hormone in rainbow trout enhances resistance to Vibrio anguillarum infection. Veterinary Immunology and Immunopathology, 57, 147-152.

Satyani, D., Mundriyanto, H., Subandiyah, S., Chumaidi, Sudarto, Taufik, P., Slembrouck, J., Legendre, M., \& Pouyaud, L. (2006). Technology of ornamental fish botia (Chromobotia macracanthus Bleeker) culture on laboratory scale. Badan Riset Kelautan dan Perikanan, Departemen Kelautan dan Perikanan.

Subaidah, S., Carman, O., Sumantadinata, K., Sukenda, \& Alimuddin. (2012). Growth response and genes expression of white shrimp Litopenaeus vannamei immersed in recombinant giant grouper growth hormone solution. Aquaculture Research Journal, 7(3), 359-369. 